\title{
Assessment of Tumour Response to Multimodalities of Treatment in Locally Advanced Breast Cancer Patients Using Comet Assay
}

\author{
K. S. Santhy, Anupama, M. Srividya, K.S. Mangayarkarasi*, P. Arulraj** and M.V. Usharani* \\ Department of Life Sciences, Avinashilingam University for Women, \\ Coimbatore 641 043, Tamil Nadu, India \\ *Department of Environmental Sciences, Bharathiar University, \\ Coimbatore 641 046, Tamil Nadu, India \\ **Department of Surgical Oncology, VNCC, GKNM Hospital, Coimbatore 641 037, \\ Tamil Nadu, India
}

KEYWORDS Tumour Response. Comet Assay.

\begin{abstract}
The present study has been carried out to evaluate tumour response to the multi-modalities of treatment using comet assay in breast cancer patients and to assess the efficacy of combinatorial therapy over single modality treatments. An effort was also made to correlate the extent of DNA damage with the cycles of chemotherapy given. A positive correlation was found with the selected comet parameters.
\end{abstract}

\section{INTRODUCTION}

The ability of surgical oncologists, medical oncologists and radiation oncologists to develop multi-disciplinary treatment plans for individual patients has served as an important tool for effective cancer management strategies Chan et al. (2006).

Response to treatment varies with stage, age, pathological condition and economic status of the patient Muss et al. (2000). Treatments are generally judged to be effective if they produce either a complete or a partial remission. A patient's responsiveness to therapy usually is determined after two to three months of the treatment. The patient's description of symptoms also plays an important role. In addition, it is important to note that there is an inter individual variability in response to therapy among patients Lou et al. (2005).

If tumour sensitivity could be predicted in advance, it may be possible to improve control rates significantly by selecting the therapy to which the tumour respond. This will help reduce the side effects for the individual patient.

Many of the patients undergoing one treatment fail to respond, and there are high chances for tumour to establish and also consequently crucial time goes waste for some ineffectual therapies Nicole et al. (2008).

If there is a possibility to assess the response rate before the crucial time reaches, it will be highly beneficial to implement an effective treatment option for patient. To assess the response, the use of the comet assay, which shows the extent of DNA damage in the peripheral lymphocytes Nadin et al. (2006), may help in the earlier identification of patients not responding to the therapy and suggests suitable therapies within the crucial time limits. The present study is undertaken to judge the treatment by comparing the efficacy of different modalities of treatment with respect to DNA damage.

\section{MATERIALS AND METHODS}

\section{Study Population}

The study was carried out on locally advanced breast cancer patients (LABC) from a hospital at Chennai. They were asked to complete a self-administered questionnaire containing details of reproductive history, medical conditions, family history and treatment conditions. Among the total of 41 subjects five were found to have distant metastasis and only one with the family history of breast cancer (Table 1). All the patients with $\mathrm{LABC}$ were undergoing different modalities of treatment, i.e., chemotherapy alone $(n=12)$, chemotherapy + surgery $(n=10)$, chemotherapy + radiotherapy 
Table 1: Clinical data of the cases studied

\begin{tabular}{|c|c|c|c|c|c|}
\hline \multirow{3}{*}{$\frac{\text { Treatment }}{\text { Chemotherapy }}$} & \multirow{2}{*}{$\frac{\text { Age }}{39}$} & \multicolumn{2}{|c|}{ Sex Cycle } & \multirow{2}{*}{$\begin{array}{c}\text { Metastasis } \\
-\end{array}$} & Parity \\
\hline & & $\mathrm{F}$ & 6 & & 2 \\
\hline & 40 & $\mathrm{~F}$ & 5 & - & 2 \\
\hline & 40 & $\mathrm{~F}$ & 2 & - & \\
\hline & 42 & M & 31 & Lung Secondaries & es \\
\hline & 53 & $\mathrm{~F}$ & 5 & - & 4 \\
\hline & 55 & $\mathrm{~F}$ & 2 & - & \\
\hline & 55 & F & 1 & - & 4 \\
\hline & 56 & F & 3 & & \\
\hline & 57 & $\mathrm{~F}$ & 1 & & \\
\hline & 57 & F & 3 & & 2 \\
\hline & 60 & $\mathrm{~F}$ & 3 & & 2 \\
\hline & 66 & $\mathrm{~F}$ & 2 & - & 4 \\
\hline Chemotherapy & 33 & $\mathrm{~F}$ & 6 & - & 2 \\
\hline+ & 35 & F & 1 & - & 3 \\
\hline Surgery & 35 & $\mathrm{~F}$ & 2 & & 2 \\
\hline$(\mathrm{n}=10)$ & 39 & F & 6 & - & 2 \\
\hline & 40 & $\mathrm{~F}$ & 1 & & \\
\hline & 45 & F & 2 & & 3 \\
\hline & 46 & $\mathrm{~F}$ & 6 & & \\
\hline & $49 *$ & $\mathrm{~F}$ & 5 & & 3 \\
\hline & 50 & $\mathrm{~F}$ & 2 & & 2 \\
\hline & 50 & M & 1 & - & \\
\hline Chemotherapy & 50 & $\mathrm{~F}$ & 21 & Lung Secondaries & es \\
\hline+ & 53 & $\mathrm{~F}$ & 1 & & 2 \\
\hline Radiotherapy & 55 & $\mathrm{~F}$ & 2 & & 2 \\
\hline$(\mathrm{N}=8)$ & 55 & $\mathrm{~F}$ & 5 & - & 2 \\
\hline & 55 & F & 4 & - & 2 \\
\hline & 55 & $\mathrm{~F}$ & 1 & - & - \\
\hline & 57 & $\mathrm{~F}$ & 4 & - & . \\
\hline & 65 & $\mathrm{~F}$ & 1 & Bone metastasis & $\mathrm{s}$ \\
\hline Surgery & 38 & $\mathrm{~F}$ & 6 & & 2 \\
\hline & 43 & $\mathrm{~F}$ & 6 & & 2 \\
\hline Radiotherapy & 46 & $\mathrm{~F}$ & 8 & & - \\
\hline & 47 & F & 5 & & 2 \\
\hline & 48 & F & 6 & & 2 \\
\hline & 52 & $\mathrm{~F}$ & 6 & & 2 \\
\hline & 53 & $\mathrm{~F}$ & 4 & Bone metastasis & 2 \\
\hline & 60 & $\mathrm{~F}$ & 6 & & 3 \\
\hline & 65 & M & 6 & & - \\
\hline & 65 & $\mathrm{~F}$ & 6 & & - \\
\hline & 70 & $\mathrm{~F}$ & 61 & Lung Secondaries & es \\
\hline
\end{tabular}

*-One with family history of breast cancer.

$(n=8)$ and chemotherapy + surgery +radiotherapy $(\mathrm{n}=11)$.

A total number of 17 healthy individuals who had no history of any type of cancer served as control subjects (age ranges from 30-60years).

\section{Comet Assay}

A few $\mu$ l of heparinised blood was collected from each subject. Each blood sample was suspended in RMPI 1640 medium with $20 \%$ fetal calf serum and were incubated for $30 \mathrm{~min}$ at $37^{\circ} \mathrm{C}$. The method of SCGE technique was followed Singh et al. (1998). In brief, blood samples after incubation were suspended in low melting agarose $(0.5 \%)$ and were layered on freshly frosted slides between regular agarose $(0.75 \%)$ and low melting agarose $(0.5 \%)$. The slides were left overnight at $4{ }^{\circ} \mathrm{C}$ in cold lysing solution with high salt concentrations (1\% Sodium Lauryl sarcosinate, $2.5 \mathrm{M} \mathrm{NaCl}, 100 \mathrm{Mm} \mathrm{Na}$ EDTA; $1 \%$ Triton X 100 and 10\% DMSO were added just before use and $\mathrm{pH}$ adjusted to 10. Slides were then given alkali treatment ( $1 \mathrm{mM} \mathrm{Na}$ EDTA, 300

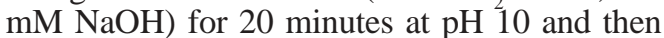
subjected to electrophoresis at 300 milli Amps and 20 Volts in the same buffer for additional 20 minutes. All the above steps were conducted in yellow light to prevent additional exogenous DNA damage. Following electrophoresis, the slides were rinsed into neutralizing buffer and stained with silver stain, sealed with coverslip.

\section{Evaluation of DNA Damage}

The cells were scored according to the degree of damage or the migration of DNA from cells after electrophoresis. For each sample at least 50 cells were scored randomly and the slides were observed at 40x objective magnification.

The frequency of intact cells, cells with short tails, cells with medium, and cells with long tails were scored.

According to their tail length cells were categorized into Type I, Type II and Type III. DNA damage was quantified for each cell by measuring the total length (head to tail).

To assess the efficacy of a particular treatment option, the data obtained for each treatment group was subjected to ANOVA. Correlation analysis was performed to assess the relationship of age of the patients Vs DNA damage and cycles of chemotherapy Vs DNA damage. Chi-square test was used for finding significance of DNA damage with respect to the parity.

\section{RESULT AND DISCUSSION}

The level of DNA damage showed variance in each therapy showing the responsiveness of the tumour. It was observed that the combinatorial modality (chemotherapy + surgery + radiotherapy) was the most effective over the single modality of treatment, i.e., chemotherapy alone. The data interpreted in combinatorial modality showed a reduced tail length and less number of damaged cells (Table 2), Type I, Type II and Type III, while the values for the same 
Table 2: Tumor response to multi modalities of treatment with reference to selected comet parameters

\begin{tabular}{|c|c|c|c|c|c|c|}
\hline Treatment & $\begin{array}{c}\text { Tail } \\
\text { Length } \\
(\mathrm{mm})\end{array}$ & $\begin{array}{c}\text { No. of } \\
\text { damaged } \\
\text { cells / } \\
50 \text { cells }\end{array}$ & $\begin{array}{c}\text { Head/tail } \\
\text { Ratio }\end{array}$ & $\begin{array}{c}\text { Type I } \\
/ 50 \\
\text { cells }\end{array}$ & $\begin{array}{c}\text { Type II } \\
\text { / } 50 \\
\text { cells }\end{array}$ & $\begin{array}{l}\text { Type III } \\
\text { / } 50 \\
\text { cells }\end{array}$ \\
\hline Chemotherapy & 22.15 & 41 & 0.05 & 8 & 22.75 & 10.13 \\
\hline Chemotherapy+Surgery & 17.09 & 38.87 & 1.12 & 7.9 & 23.63 & 7.25 \\
\hline Chemotherapy+Radiotherapy & 14.60 & 40.27 & 1.19 & 12.75 & 22.63 & 4.75 \\
\hline Chemotherapy+Surgery+Radiotherapy & 11.08 & 34.5 & 1.39 & 13.50 & 17 & 4.13 \\
\hline Controls & 01.49 & 5.63 & 1.49 & 4.13 & 1.88 & 0.25 \\
\hline F value & $8.473 * *$ & $19.86 * *$ & $1.509^{\mathrm{NS}}$ & $5.85 * *$ & $7.729 * *$ & $6.735 * *$ \\
\hline $\mathrm{CD}$ & 6.09 & 8.12 & 0.046 & 4.49 & 7.0 & 3.28 \\
\hline S.E & 2.124 & 1.26 & - & 1.323 & 2.636 & 1.135 \\
\hline
\end{tabular}

** Significant at $\mathrm{p}=0.01$

NS - Non significant

parameters were found to be higher in the patients undergoing other modalities, namely, chemotherapy +radiotherapy, chemotherapy + surgery and chemotherapy alone respectively.

The present study reported a consistent association between DNA damage and different modalities of treatments. The association was most strongly indicated by reduced values of comet parameters when the locally advanced breast cancer patients opted for chemotherapy + surgery + radiotherapy showing the significance of combined modalities.

Natsugoe et al. (2006) in their study of recurrence of oesophageal squamous cell cancer, found a significant survival rate from recurrence to mortality in patients who underwent surgery + other therapy $(6.7 \%)$ in comparison to no survival in patients undergone chemotherapy alone $(0 \%)$ equal to the patients without any treatment. The above finding shows relevance of present study which reported limitation of chemotherapy alone in comparison to combined therapy viz. chemotherapy + surgery + radiation therapy.

The study has shown a comparatively high DNA damage in patients undergoing the chemotherapy alone, showing the limitations of using single modality of the treatment. Halder et al. (2002) also observed severe degree of damage of DNA at the relapsed stage of post chemotherapy induced patients with little or no immature cells seen in peripheral blood and bone marrow, supporting a short term benefits of chemotherapy alone.

Wolf et al. (1991) also demonstrated that there is no significant difference in survival between patients having induction chemotherapy and radiation verses surgery and radiation in respectable advanced stages squamous cell carcinoma of the larynx. However, the larynx was preserved in $64 \%$ of the patients who received induction chemotherapy and radiation therapy. This data supports the idea of initial chemotherapy followed by radiation, instead of surgical management of the tumour. In our study, the tumour response to chemotherapy + radio therapy was higher than that of chemotherapy + surgery thereby, it suggests conservation of breast tissue by avoiding surgery.

An attempt was made to compare the DNA damage profile with the age of the patients irrespective of the cycles of chemotherapy. A positive correlation was observed between age of the patients and the DNA damage (Table 3 ). It was found that DNA damage is more in older patients as compared with younger patients.

The above findings corroborate with the study of Deffaud et al. (1997) and Peace and Succop(1999) who observed an increase in the frequency of affected cells with aging. This could be attributed to the accumulation of genetic damage in the cells or to the aging process, such

Table 3: Correlation between extent of DNA damage and age of the patients / chemotherapy cycles

\begin{tabular}{lll}
\hline Parameters & $\begin{array}{c}\text { Age } \\
\text { of the } \\
\text { patients }\end{array}$ & $\begin{array}{c}\text { Cemo- } \\
\text { therapy } \\
\text { cycles }\end{array}$ \\
\hline Tail length (mm) & +0.012 & -0.112 \\
No. of damaged cells/ 50 cells & +0.10 & -0.088 \\
Head - tail ratio & +0.014 & +0.060 \\
Type - I & -0.326 & +0.327 \\
Type - II & +0.197 & -0.27 \\
Type - III & -0.064 & -0.066 \\
\hline
\end{tabular}


as altered cellular metabolism and decrease in the efficiency of DNA repair.

An American study by Singh et al. (1991) detected a $12 \%$ increase in the basal level of DNA damage among individuals of above 60 years of age compared with individuals of below 60 years, which was ascribed to a 5 fold higher content of highly damaged cells among older individuals.

A negative correlation was found between cycles of chemotherapy and comet parameters (Table 4). When the cycles of chemotherapy goes up these patients showed less DNA damage as compared to the initial cycles of chemotherapy, which indicates that the tumour is responding well to the chemotherapy. In some cases, it is not so because they are not responding to the chemotherapy.

Table 4: Head-tail ratio ( $>1 \mathrm{~mm}$ and $<1 \mathrm{~mm})$ of parous and Nulliparous samples studied

\begin{tabular}{lccc}
\hline Head - Tail Ratio & $>1$ im & $<1$ im & Total \\
\hline Parous & 36 & 16 & 52 \\
Nulliparous & 7 & 2 & 9 \\
\hline Total & 43 & 18 & 61 \\
\hline
\end{tabular}

$\chi^{2}=0.268 ; \mathrm{p}<\mathrm{t} 0.05$

Data pertaining to parity was interpreted and presented in Table 4 for DNA damage studies in patients and controls. The samples with nulliparity $(n=9)$ and parity $(n=52)$ were grouped according to the damage profile (head to tail ratio) above $1 \mu \mathrm{m}$ and below $1 \mu \mathrm{m}$, irrespective of the stage, age and treatment option. The results were insignificant, indicating that parity may not affect the DNA.

In conclusion it may be stated, if comet assay is carried out after three cycles of chemotherapy with a baseline comet assay before starting the next cycles of chemotherapy, the tumour responses can be assessed at the molecular level thereby to suggest a change in the modality of treatment as per the results. The present study although a preliminary, plays an important role in deciding the modality of treatment thereby enhances the recovery rates.

\section{REFERENCES}

Deffaud F, Orsiere T, Villani P, Pelissier AL, Volot F, Favre R, Botta A 1997. Comparison between micronucleated lymphocyte rates observed in healthy subjects and cancer patients. Mutagen, 12: 227-237.

Halder A, Bandyopadhyay D, De M, Manisha De 2002. Detection of DNA damage measured by comet assay in pre and post chemotherapeutic acute lymphoblastic leukaemia. Int J Hum Genet, 2(3): $209-$ 211.

Hyman B, Muss H, Cohen H, Lichtman S 2000.Clinical research in the older cancer patients. Hematology / Oncology Clinics of North America, 14(1): 283291 .

Lou J, Jin L, Zheng W, Wang B and Deng H 2005. Measuring the genetic damage in cancer patients during radiotherapy with 3 genetic end points. Mutagenesis, 19(6): 457 - 464.

Natsugoe S, Okumura H, Matsumoto M, Uchikado Y, Setoyama T, Uenosono Y, Ishigami S, Owaki T, Aikou T 2006. The role of salvage surgery for recurrence of esophageal squamous cell cancer. Eur $J$ Surg Oncol,12: 1 - 51.

Nadin S, Vargas-Roig L, Drago G, Ibarra J,Ciocia D 2006. DNA damage and repair in peripheral blood lymphocytes from healthy individuals and cancer patients. A pilot study on the implications in clinical response to chemotherapy. Cancer Letters, 239(1): 84-97.

Nicole E, Willmarth, Stephen P, Ethier 2008. Amphiregulin as a novel target for breast cancer therapy. Journal of Mammary Gland Biology and Neoplasia. 13(2): 171 - 179.

Peace BE, Succop P 1999. Spontaneous micronucleus frequency and age: what are normal values? Mut Res, 425: 225-230.

Singh NP, McCoy MT, Tice RR, Schneider EL 1998. A simple technique for quantification of low levels of DNA damage in individual cells. Experimental Cell Research, 175: 184-191.

Singh NP, Danner DB, Tice RR, Pearson JD, Brant LJ, Morrell CH, Schneider EL 1991. Basal DNA damage in individual human lymphocytes with age. Mutat Res, 256: 1-6.

Wai-Fan Chan, Polly Suk-Yer Cheung, Richard J, Epstein, Joyce Mak 2006. Multidisciplinary approach to the management of breast cancer in Hong Kong. World Journal of Surgery, 30(12): 2095-2100

Wolf GT, Hong WK, Fisher SG 1991. Induction chemotherapy plus radiation compared with surgery plus radiation in patients with advanced laryngeal cancer. $N$ Eng J Med, 324: 1685-1690 